Case Report

\title{
Leucism in South American Lungfishes Lepidosiren paradoxa Fitzinger, 1837 (Osteichthyes, Dipnoi, Lepidosirenidae) from Argentina
}

\author{
Luis A. Romano ${ }^{1 *}$, Virgínia F. Pedrosa ${ }^{1}$ \\ ${ }^{1}$ Laboratory of Immunology and Pathology of Aquatic Organisms, Institute of Oceanography, Federal University of Rio Grande, Rio Grande, Brazil. \\ "Corresponding author: Luis Alberto Romano, Laboratory of Immunology and Pathology of Aquatic Organisms, Institute of Oceanography, Federal \\ University of Rio Grande (RS), 96210-030, Brazil. E-mail: luisalbertoromano0@ gmail.com
}

Submitted September, $25^{\text {th }} 2019$, Accepted January, $28^{\text {th }} 2020$

\begin{abstract}
The present study reports a case of leucism in South American Lungfish Lepidosiren paradoxa captured in Corrientes, Argentina. It was observed a change in cutaneous pigmentation, and it was concluded that it was leucism and not albinism, since there was a decrease of tegumentary melanin pigment and normal pigmentation in the retina.
\end{abstract}

Key words: leucism, lungfish, pigmentation.

\section{Introduction}

Within the animal kingdom, several species are endowed with the ability to change the body color, by means of some behaviors that contribute to their survival. Several factors can influence the coloration of animals, some animals change their body coloration to camouflage themselves, others to draw the attention of the opposite sex, others to avoid the predator's action (12).

Some animals have a color or color pattern so marked that when an individual appears in nature with different coloring than normal, this modification seen as an abnormality. Among the anomalies which alter the color of the animals, albinism is the most well-known, but it is easily confused with leucism, which distinguishes itself by the loss of cutaneous pigmentation, which is partial in the latter, with the retina normally keeping its pigmentary epithelium (8). Leucism generates a white color to animals differing from the usual color of the species. It can be partial or total, with only some parts of the body of the animal with white coloration, or the entire body region with such coloring (10).

The South American Lungfish (Lepidosiren paradoxa) is found in marshes and slow waters of the Amazon and Paraguay rivers and in the lower basins of the
Paraná River in South America. This species, by having lungs, can perform gas exchange with the air, being the only member of the family Lepidosirenidae (6). The juvenile animals feed of larvae of insects and snails, while some adults are omnivores, adding algae and shrimps to their diet and crush them with their highly mineralized dental plates. The daily habitat of the fish disappear during the dry season, a time that they lurk in the mud and form a hole in the shape of a camera to a $30-50 \mathrm{~cm}$ beneath the surface in the mud, leaving some holes on the surface so that the air enters. The skin has important functions, producing a layer of mucus to seal moisture and decrease its metabolism, as well as participate in the breathing of the animal (4).

\section{Case report}

Three juvenile copies of $L$. paradoxa were caught by sports fishermen in an area with mud and water scarce in Esteros del Ibera, province of Corrientes, Argentina. The length of the animals was 110,107 and $125 \mathrm{~mm}$. One of them showed changes in skin pigmentation, with the whole-body surface of white-pinkish color, but its eyes were pigmented (Fig. 1 and 2). In the literature review, 
only one case was found of albinism in L. paradoxa and no case of leucism (1).

There are studies that suggest that the pigment anomalies in wild animals may be an indicator of various environmental situations as an effect of contaminants (3, 9). Since the pigment cells as the melanophores are derived from the neural crest $(7,11)$, it is possible that some kind of environmental stress, produced by contaminants such as heavy metals is capable of damaging the neural crest and change the distribution of melanophores $(2,5)$.

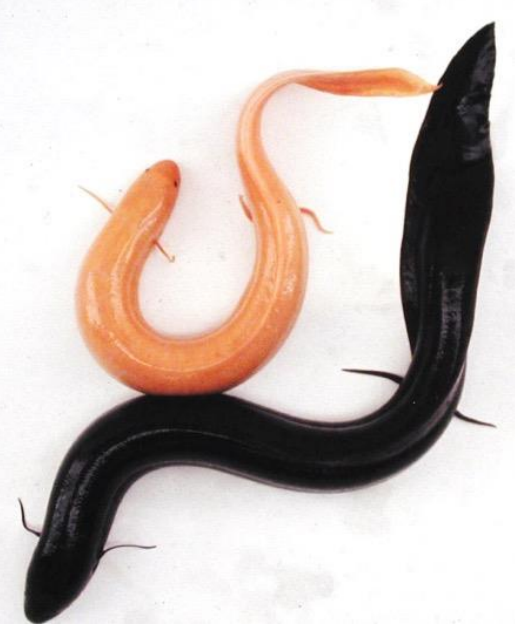

Figure 1. Two specimens of L. paradoxa, the superior with leucism and the inferior with normal pigmentation. Bar $=1.5 \mathrm{~cm}$.

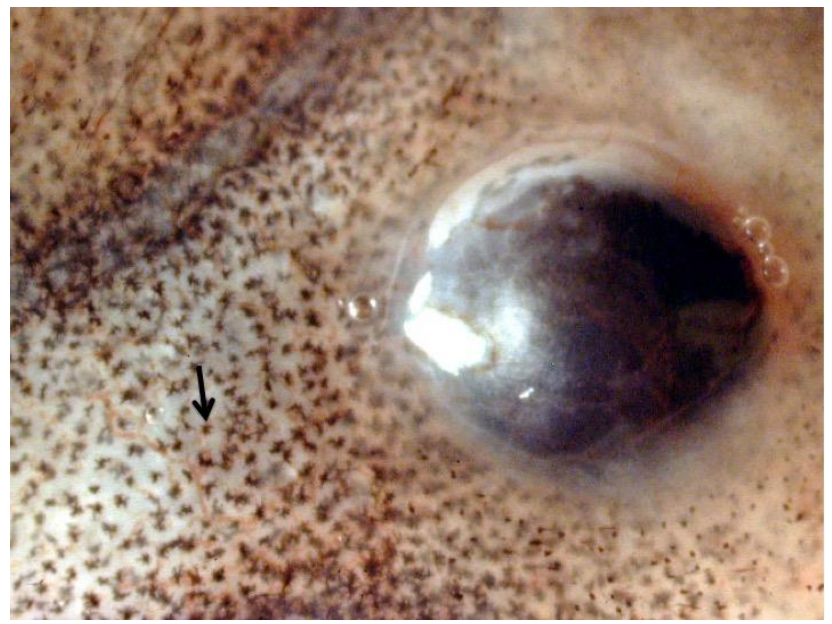

Figure 2. Detail of the ocular area where it is possible to see the pigmented eye and several melanophores (arrow).

On the other hand, these fishes live quite isolated, and it is possible that the populational insulation increases the occurrence of inbreeding propitiating the manifestation of chromatic aberrations. However, it is not possible to ensure that this is the cause, once it is necessary to conduct further studies on the genetic variability of the species studied to prove this hypothesis.

\section{Acknowledgments}

L.A. Romano is a research fellow of the National Council for Scientific and Technological Development, 301245/2016-9.

\section{References}

1. Azpelicueta MM, Braga L. Albinismo en Lepidosiren paradoxa Fitzinger, 1837 (Osteichthyes, Dipnoi, Lepidosirenidae). Neotropica, Buenos Aires, Argentina. 1984;30(83):75-8.

2. Baggio H, Horn AH. Teores totais e distribuição dos metais pesados $\mathrm{Cu}, \mathrm{Cd}, \mathrm{Cr}, \mathrm{Ni} \mathrm{Pb}$ e $\mathrm{Zn}$ nos sedimentos de corrente e fundo do rio do FormosoMG. Geografias. 2010;6:107-17.

3. Bensch S, Hansson B, Hasselquist D, Nielsen B. Partial albinism in a semi-isolated population of great reed warblers. Hereditas. 2000;133:167-70.

4. Bruton MN, Paxton JR, Eschmeyer WN, editors. Encyclopedia of Fishes. San Diego: Academic Press. 1998, pp 709-716

5. Coelho-Aguiar JM, Le Douarin NM, Dupin E. Environmental factors unveil dormant developmental capacities in multipotent progenitors of the trunk neural crest. Developmental Biology. 2013;384:1325.

6. Froese R, Pauly D. "Lepidosiren paradoxa" in FishBase. April 2014 version. 2014. pp 102- 104

7. Le Douarin N. The Neural Crest. Cambridge University Press. Cambridge. 1982. pp 342- 354

8. Medina C, López E. Primer registro de leucismo en Sturnira lillium (Pyllostomidae) en el sureste de Perú. Chiroptera Neotropical. 2010;16(2):758-61.

9. Quigley DTG, Lord R, MacGabhann D, Flannery K. First records of xanthochromism in three-bearded rockling Gaidropsarus vulgaris (Cloquet, 1824) and pollack Pollachius pollachius (Linnaeus, 1758). J Appl Ichthyol. 2017;33(6):1208-10.

10. Quigley DTG, de Carlos A, Barros-Garcia D, MacGabhann D. Albinism and leucism in Blonde Rays (Raja brachyura Lafont, 1871) (Elasmobranchii: Batoidea) from the Irish Sea. Bull.Eur. Ass.Fish Pathol. 2018;38:79-88.

11. Sadaghiani B, Vielkind JR. Neural crest development in Xiphophorus fishes: Scanning electron and light microscopic studies. Development. 1989;105:487504.

12. Van Grouw H. Not every white bird is an albino: sense and nonsense about color aberrations in birds. Dutch Birding. 2006;28:79-89. 